\title{
TINGKAT PARTISIPASI MASYARAKAT TERHADAP PROGRAM PEMBANGUNAN GEMMA TAPIS BERSERI DI KECAMATAN KEDATON KOTA BANDAR LAMPUNG
}

\author{
Asmaria $^{1}$, Lies Kumara Dewi' ${ }^{2}$ M.Fikri Akbar ${ }^{3}$ \\ ${ }^{123}$ Fakultas Ilmu Sosial Dan Ilmu Politik, Universitas Sang Bumi Ruwa Jurai, Lampung \\ Email: asmariafisip@gmail.com
}

\begin{abstract}
According to the regulation letter from the Mayor of Bandar Lampung Number 12 of 2006 concerning the Gemma Tapis Berseri City Bandar Lampung Development Program, a movement carried out by and for the people of Bandar Lampung City, to do it well together. In an effort to develop the people's economy. The use of the name Tapis Berseri in the Development Movement is also associated with the motto of the City of Bandar Lampung. This study aims to determine the extent of the effect of community participation on the gemma tapis serial development program in the Kedaton District, Bandar Lampung City. In this study using the type of expansion that is research conducted to test the relationship between two variables or explain the relationship between two variables. The magnitude of the effect of community participation on the Gemma Tapis Berseri Development Program is $26.06 \%$, whereas from the calculation of the hypothesis test $t$ test gets a figure of 6.448 and the results of the $t$ table at a significant level of $5 \%$ of 2,000 and at a significant level of $1 \% \mathrm{t}$ table of 2.660 so $t$ count is greater than $t$ table or $2,000<6.448>2.660$. From the results of the calculation above shows that community participation has a positive and significant effect on the Gemma Tapis Berseri Development Program in Kedaton District, Bandar Lampung City, thus the hypothesis proposed by the author is proven and accepted.
\end{abstract}

Keywords: Community, Participation, Radiant Tapis echo

\begin{abstract}
ABSTRAK
Menurut surat peraturan dari Walikota Bandar Lampung Nomor 12 Tahun 2006 tentang Program Pembangunan Gemma Tapis Berseri Kota Bandar Lampung, suatu gerakan yang dilakukan oleh dan untuk masyarakat Kota Bandar Lampung, untuk melakukannya secara baik bersama. Dalam upaya pengembangan ekonomi masyarakat. Penggunaan nama Tapis Berseri dalam Gerakan Pembangunan ini dikaitkan juga dengan motto Kota Bandar Lampung. Penelitian ini bertujuan untuk mengetahui sejauh mana pengaruh partisipasi masyarakat terhadap program pembangunan gemma tapis berseri di Kecamatan Kedaton Kota Bandar Lampung. Dalam penelitian ini menggunakan tipe eksplansi yaitu penelitian yang dilakukan untuk menguji hubungan antara dua variabel atau menjelaskan hubungan antara dua variabel. Besarnya pengaruh partisipasi masyarakat terhadap Program Pembangunan Gemma Tapis Berseri adalah sebesar 26,06\%, sedangkan dari perhitungan pengujian hipotesis uji t mendapatkan angka sebesar 6,448 dan hasil $t$ tabel pada taraf signifikan $5 \%$ sebesar 2,000 dan pada taraf signifikan $1 \% \mathrm{t}$

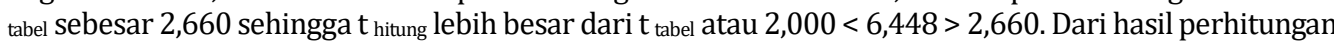
tersebut di atas menunjukkan partisipasi masyarakat berpengaruh positif dan signifikan terhadap Program Pembangunan Gemma Tapis Berseri di Kecamatan Kedaton Kota Bandar Lampung, dengan demikian hipotesis yang penulis ajukan terbukti dan diterima.
\end{abstract}

Kata kunci: Partisipasi, Masyarakat, Gema Tapis Berseri

* Copyright (c) 2020 Asmaria, Lies Kumara Dewi dan M.Fikri Akbar

This work is licensed under a Creative Commons Attribution-ShareAlike 4.0 International License.

Diterima: 7 April 2020; Direvisi: 24 April 2020; DIsetujui: 27 April 2020 


\section{Khazanah Sosial, Vol. 2 No. 1: 1-14}

Tingkat Partisipasi Masyarakat Terhadap Program Pembangunan Gemma Tapis Berseri di Kecamatan

Kedaton Kota Bandar Lampung

Asmaria, Lies Kumara Dewi dan M.Fikri Akbar

\section{PENDAHULUAN}

Keterlibatan masyarakat dalam pembangunan adalah upaya pemerintah daerah untuk mengelola pembangunan sebagai salah satu upaya kemandirian daerah dengan memberikan inisiatif lokal, peran yang lebih besar dan memastikan partisipasi masyarakat dalam perencanaan pembangunan, implementasi dan pengawasan pembangunan (Bihamding, 2019). Dalam perspektif ini, pemerintah mencoba untuk memobilisasi partisipasi masyarakat dalam pembangunan dengan membuka lebih banyak ruang bagi masyarakat untuk terlibat langsung dalam proses pembangunan. Partisipasi masyarakat harus lengkap, mulai dari bentuk perencanaan kegiatan, pelaksanaan, hingga pengawasan bersama dan bukan dari partisipasi yang dilakukan karena dipaksakan, tetapi ada kehendak setiap individu masyarakat yang sadar pembangunan. Partisipasi ini juga dapat melihat perluasan partisipasi masyarakat dalam pembangunan yang dimulai dengan perencanaan, implementasi, dan pengawasan. Partisipasi masyarakat adalah bentuk kegiatan atau implementasi, bukan hanya sikap. Bentuk partisipasi masyarakat yang diharapkan adalah untuk bersama-sama memberikan ide-ide inovatif, serta staf untuk melaksanakan program pembangunan dan melakukan pemantauan, tidak hanya sikap terhadap pencapaian pembangunan, tetapi dalam bentuk kegiatan yang dilakukan bersama (Tuasikal, 2013).

Partisipasi masyarakat berdasarkan Pedoman Pelaksanaan Gerakan Masyarakat Membangun (Gemma) Tapis Berseri 2006 yaitu proses pelaksanaan program atau kegiatan yang direncanakan mengedepankan partisipasi dan keterlibatan masyarakat secara aktif baik dalam bentuk pembiayaan, tenaga kerja, bahan material, maupun ide dan pemikiran, mulai dari perencanaan, pelaksanaan, serta pengawasan. Bentuk partisipasi masyarakat dimulai dengan perencanaan, pelaksanaan, serta pengawasan. Karena bentuk partisipasi masyarakat yang baik yaitu dilibatkan secara aktif dalam pembangunan, bukan sebaliknya masyarakat hanya sebagai penerima saja dalam pembangunan (Lubis \& Mayarni, 2017). Hal ini, partisipasi masyarakat yang baik adalah terlibat secara aktif dalam tahap-tahap perencanaan, pelaksanaan serta pengawasan pembangunan (Deviyanti, 2013). Bukan hanya sebagai individu yang menerima tetapi ikut berpartisipasi dalam pembangunan. Dengan demikian, tingkat partisipasi masyarakat dapat dilihat melalui keterlibatan secara langsung dimulai dari tahap perencanaan, pelaksanaan dan pengawasan.

Berdasarkan surat Peraturan Walikota Bandar Lampung Nomor: 12 Tahun 2006 tentang Program Pembangunan Gemma Tapis Berseri Kota Bandar Lampung yaitu suatu gerakan yang dilakukan oleh, dari, dan untuk masyarakat Kota Bandar Lampung untuk berbuat kebaikan secara bersama dalam upaya pengembangan ekonomi masyarakat (Susanti, 2017). Penggunaan nama Tapis Berseri dalam Gerakan Pembangunan ini dikaitkan juga dengan motto Kota Bandar Lampung itu sendiri. Salah satu kecamatan di Kota Bandar Lampung yang melaksanakan kegiatan Program Pembangunan Gemma Tapis Berseri adalah Kecamatan Kedaton. Kecamatan ini menarik untuk diteliti karena tingkat perekonomian masyarakat yang berbeda, latar belakang pendidikan yang berbeda dalam masyarakat, serta mata pencaharian yang berbeda juga, dan letak yang strategis dengan pusat kota. Selain itu juga, Penulis dapat dengan mudah melihat tingkat partisipasi masyarakat dalam menjalankan program pembangunan Gemma Tapis Berseri yang dimulai dari tahap perencanaan, pelaksanaan dan pengawasan.

Partisipasi Masyaraka Menurut Taliziduhu Ndraha (1990), peningkatan partisipasi berarti bahwa setiap orang atau setiap warga negara, pria dan wanita, harus memiliki hak suara yang sama dalam proses pengambilan keputusan, baik secara langsung maupun melalui lembaga perwakilan berdasarkan minat dan kepentingan masing-masing. Menurut Putri (2019), partisipasi adalah konsekuensinya di bagian kegiatan bersama. Pernyataan beberapa ahli tersebut dapat ditarik suatu kesimpulan bahwa bentukbentuk partisipasi masyarakat dalam pembangunan yaitu masyarakat secara bersama-sama ikut 


\section{Khazanah Sosial, Vol. 2 No. 1: 1-14}

Tingkat Partisipasi Masyarakat Terhadap Program Pembangunan Gemma Tapis Berseri Di Kecamatan

Kedaton Kota Bandar Lampung

Asmaria, Lies Kumara Dewi dan M.Fikri Akbar

memberikan masukan pemikiran serta tenaga dalam proses pembangunan dan disamping masyarakat yang ikut memberikan masukan serta pemikirannya mereka harus memelihara dan mengembangkan hasil pembangunan yang dibangun secara bersama-sama. Penelitian tentang partisipasi dirasa masih kurang dan membutuhkan kajian lebih lanjut .

\section{METODE PENELITIAN}

Dalam pelaksanaan program Pembangunan Gemma Tapis berseri di Kota Bandar Lampung berdasarkan Peraturan Walikota Bandar Lampung Nomor 12 Tahun 2006 tentang Program pembangunan Gemma tapis Berseri dapat dilihat dari tingkat partisipasi masyarakat mulai dari tahap perencanaan kegiatan, tingkat pelaksanaan kegiatan dan pengawasan ataupun monitoring kegiatan. Hal ini dilakukan bahwa untuk keberhasilan suatu program kegiatan harus terencana dan sesuai dengan tempat masyarakat yang akan melaksanakan program kegiatan tersebut. Partisipasi masyarakat terdiri dari tahap perencanaan, pelaksanaan, dan pengawasan memiliki peranan serta fungsi yang berbeda. Dengan adanya partisipasi tersebut diharapkan terwujudnya swadaya masyarakat dalam proses pembangunan dan pada akhirnya konsekuensi suatu program pembangunan akan terwujud. Berdasarkan uraian di atas, maka pada gambar 1 dapat digambarkan suatu paradigma penelitian:

\begin{tabular}{|c|c|}
\hline $\begin{array}{c}\text { Variabel } \mathbf{X} \\
\text { Partisipasi Masyarakat }\end{array}$ & $\begin{array}{c}\text { Variabel Y } \\
\text { Program Pembangunan Gemma }\end{array}$ \\
\hline $\begin{array}{l}\text { 1. Partisipasi dalam Tahap Perencanaan } \\
\text { 2. Partisipasi dalam Tahap Pelaksanaan } \\
\text { 3. Partisipasi dalam Tahap Pengawasan } \\
\text { (Gang) }\end{array}$ & $\begin{array}{l}\text { 1. Perencanaan Program } \\
\text { Pembangunan Gemma Tapis } \\
\text { Berseri } \\
\text { 2. Pelaksanaan Program } \\
\text { Pembangunan Gemma Tapis } \\
\text { Berseri }\end{array}$ \\
\hline
\end{tabular}

Gambar 1. Paradigma Penelitian Pengaruh Partisipasi Masyarakat Terhadap Program Pembangunan Gemma Tapis Berseri

\section{Hipotesis}

Sebagai tahap awal dalam melakukan penelitian maka perlu dirumuskan dahulu suatu hipotesis. Menurut Sutrisno Hadi, hipotesis adalah "Dugaan sementara yang mungkin benar atau mungkin salah dan akan diterima jika fakta-fakta membenarkan penolakannya dan menerima hipotesis sangat bergantung pada hasil-hasil penyelidikan terhadap fakta-fakta yang dikumpulkan" (Suliyanto \& MM, 2017).

Atas dasar pengertian tersebut di atas maka hipotesis yang diajukan dalam penelitian ini sesuai dengan permasalahan yang telah dikemukakan untuk diteliti adalah : "Terdapat Pengaruh yang Positif dan Signifikan antara Tingkat Partisipasi Masyarakat Terhadap Program Pembangunan Gemma Tapis Berseri di Kecamatan Kedaton Kota Bandar Lampung".

Dalam penelitian ini menggunakan tipe eksplansi yaitu penelitian yang dilakukan untuk menguji hubungan antara dua variabel atau menjelaskan hubungan antara dua variabel. 


\section{Khazanah Sosial, Vol. 2 No. 1: 1-14}

Tingkat Partisipasi Masyarakat Terhadap Program Pembangunan Gemma Tapis Berseri di Kecamatan

Kedaton Kota Bandar Lampung

Asmaria, Lies Kumara Dewi dan M.Fikri Akbar

\section{Definisi Variabel dan Pengukurannya}

\section{Variabel Bebas (X)}

Partisipasi masyarakat yaitu keterlibatan masyarakat dalam proses pengambilan keputusan memberikan masukan ide yang bertujuan memecahkan permasalahan serta mencari jalan keluar untuk memajukan pembangunan masyarakat secara bersama-sama. Adapun yang menjadi indikator variabel faktor-faktor yang berpengaruh adalah sebagai berikut :

1. Tahap Perencanaan

a. Sosialisasi kepada masyarakat dalam bentuk memberikan penyuluhan terkait program Gemma Tapis Berseri.

b. Ikut serta masyarakat dalam pemilihan pengurus Kelompok Masyarakat (Pokmas).

c. Ikut serta masyarakat dalam musyawarah berupa memberikan pertanyaan dan berdiskusi bersama.

2. Tahap Pelaksanaan

a. Ikut Serta masyarakat dalam pembangunan gorong-gorong, paving block dan rehab fasilitas umum (Pos jaga, tempat peribadatan, dan perbaikan jalan).

b. Tingkat swadaya masyarakat dalam pelaksanaan pembangunan berupa menyumbang material dan berupa uang serta tenaga.

c. Ikut serta masyarakat dalam pelaksanaan pengumpulan dana yaitu dengan cara meminta bantuan sumbangan kepada masyarakat untuk pembangunan

3. Tahap Pengawasan

a. Ikut serta masyarakat dalam mengawasi keluar masuknya dana melalui hasil laporan kegiatan.

b. Ikut serta masyarakat dalam mengawasi kualitas Bangunan infrastruktur yang telah dibangun serta dapat dimanfaatkan secara baik seperti paving block disetiap jalan yang kecil (Gang).

\section{Variabel Terikat (Y)}

Peningkatan Program Pembangunan Gemma Tapis Berseri adalah suatu gerakan yang dilakukan oleh, dari, dan untuk masyarakat untuk berbuat kebaikan secara bersama dalam upaya pengembangan ekonomi masyarakat.

Adapun yang menjadi indikator variabel peningkatan program pembangunan Gemma Tapis Berseri adalah sebagai berikut :

1. Perencanaan Program Pembangunan Gemma Tapis Berseri

a. Kesesuaian dengan asal usul masyarakat setempat

b. Kesesuaian dengan kondisi sosial budaya masyarakat setempat

c. Penetapan kebijakan, program dan kegiatan yang sesuai dengan esensi masalah dan prioritas kebutuhan masyarakat (Herlintati et al., 2020)

2. Pelaksanaan Program Pembangunan Gemma Tapis Berseri

a. Pembangunan bidang agama

b. Pembangunan bidang transportasi jalan

c. Pembangunan bidang keamanan

\section{Jenis dan Sumber Data}

Adapun jenis dan sumber data yang dipergunakan dalam penelitian ini adalah bersumber dari : 


\section{Khazanah Sosial, Vol. 2 No. 1: 1-14}

Tingkat Partisipasi Masyarakat Terhadap Program Pembangunan Gemma Tapis Berseri Di Kecamatan

Kedaton Kota Bandar Lampung

Asmaria, Lies Kumara Dewi dan M.Fikri Akbar

a. Data primer (data pokok) yaitu data yang dioleh peneliti secara langsung dari lapangan adalah dengan melakukan observasi, wawancara, serta kuisioner terhadap objek.

b. Data sekunder (data penunjang) yaitu data yang diperoleh peneliti dengan cara melihat literatur, dokumentasi yang ada hubungan dengan penelitian ini.

\section{Populasi dan Sampel}

\section{Populasi}

Populasi adalah sekumpulan objek yang dijadikan sarana penelitian dan memiliki karakteristik tertentu (Martono, 2019), adapun yang menjadi populasi dalam penelitian ini adalah masyarakat di Kecamatan Kedaton Kota Bandar Lampung.

\section{Sampel}

Sampel merupakan bagian dari populasi yang akan diteliti secara sesungguhnya (Sugiyono, 2015). Dalam penelitian ini digunakan teknik pengambilan sampling yaitu Two Stage Random Sampling, yaitu untuk menentukan sampel bila obyek yang akan diteliti atau sumber data sangat luas, misalnya penduduk dari suatu negara, propinsi, kabupaten atau kecamatan.

Proses pengambilan sampel dalam penelitian ini yaitu dari delapan kelurahan di Kecamatan Kedaton diambil 4 kelurahan. Kemudian dari 4 kelurahan tersebut diambil secara random dengan kuota untuk masing-masing kelurahan sebanyak 30 orang. Proses penarikan sampel dapat dilihat pada gambar 2 .

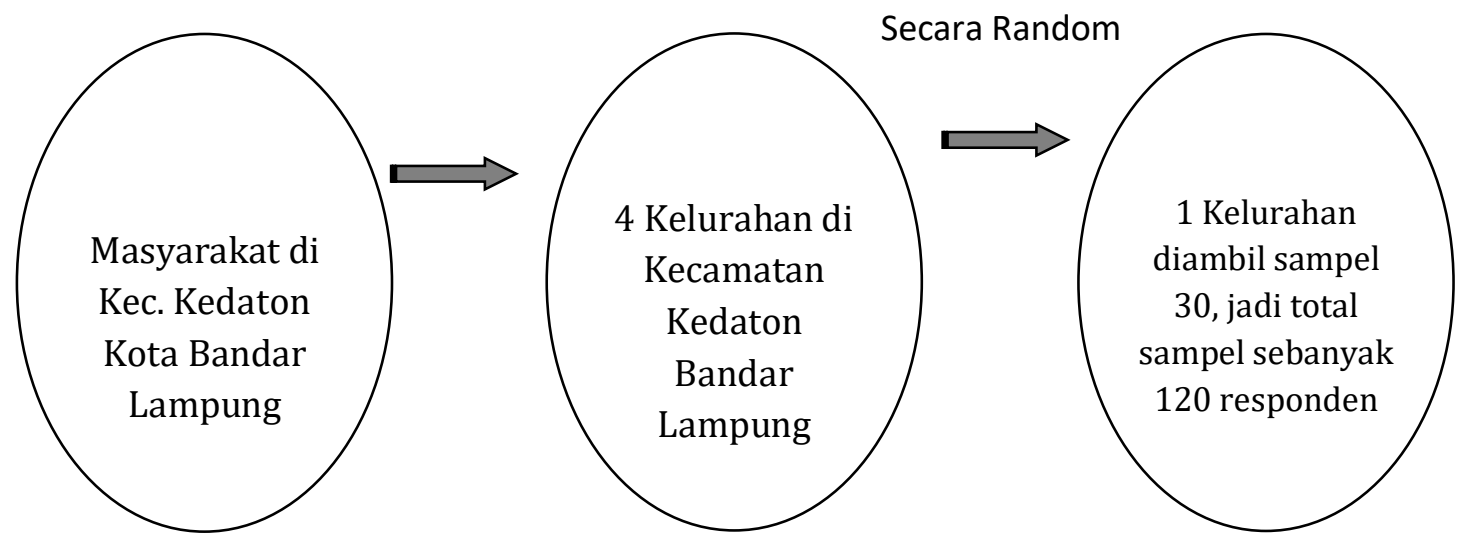

\section{Gambar 2. Proses Penarikan Sampel}

Jadi, jumlah sampel dalam penelitian ini berjumlah 120 responden dari 4 Kelurahan di Kecamatan Kedaton. Dengan demikian, teknik pengambilan sampel ini merupakan teknik Probability Sampling, sehingga data yang dikumpulkan valid dan reliable. Untuk lebih jelasnya dapat dilihat pada tabel 1:

Tabel 1. Jumlah Sampel

\begin{tabular}{|c|l|c|}
\hline No & Nama Kelurahan & $\begin{array}{c}\text { Jumlah } \\
\text { (Orang) }\end{array}$ \\
\hline 1. & Sidodadi & 30 \\
\hline 2. & Labuhan Ratu & 30 \\
\hline 3. & Sepang Jaya & 30 \\
\hline 4. & Suka Menanti & 30 \\
\hline
\end{tabular}




\section{Khazanah Sosial, Vol. 2 No. 1: 1-14}

Tingkat Partisipasi Masyarakat Terhadap Program Pembangunan Gemma Tapis Berseri di Kecamatan

Kedaton Kota Bandar Lampung

Asmaria, Lies Kumara Dewi dan M.Fikri Akbar

\begin{tabular}{|c|c|}
\hline Total (Orang) & 120 \\
\hline
\end{tabular}

\section{Teknik Pengumpulan Data}

Teknik pengumpulan data yang dipergunakan dalam penelitian ini adalah :

\section{Studi Kepustakaan (Library Research)}

Adalah suatu cara mengumpulkan data dengan membaca, memahami dan mengutip bahan bacaan yang ada hubungannya dengan materi penulisan skripsi ini. Bahan bacaan yang dimaksud antara lain meliputi buku-buku literatur, peraturan perundangan dan lain sebagainya.

\section{Studi Lapangan (Field Research)}

Adalah dilakukan untuk memperoleh data dengan cara mengadakan penelitian langsung di lokasi penelitian dengan menggunakan teknik pengumpulan data sebagai berikut :

Dokumentasi adalah penelitian yang dilakukan secara sistematis terhadap catatan-catatan atau dokumen sebagai sumber data.

Angket (kuesioner) yaitu pengumpulan data dengan cara memberikan daftar pertanyaan secara tertulis kepada responden yang akan menjadi subyek penelitian.

Pada angket tersebut dipersiapkan masing-masing variabel sebanyak 10 pertanyaan, 3 alternatif jawaban, setiap pertanyaan disajikan dalam bentuk multiple choice item

\section{HASIL DAN PEMBAHASAN}

\section{Program Pembangunan Gemma Tapis Berseri}

Tinjauan mengenai Program Pembangunan Gemma Tapis Berseri ini bersumber pada buku panduan petunjuk teknis Program Gemma Tapis Berseri yang berdasarkan Peraturan Walikota Bandar Lampung Nomor: 12 Tahun 2006. Dengan adanya pedoman kegiatan ini diharapkan dalam tahap perencanaan, pelaksanaan dan pengawasan berjalan dengan baik sesuai serta tepat sasaran. Berdasarkan surat Peraturan Walikota Bandar Lampung Nomor: 12 Tahun 2006 tentang program Pembangunan Gemma Tapis Berseri Kota Bandar Lampung yaitu suatu gerakan yang dilakukan oleh, dari, dan untuk masyarakat Kota Bandar Lampung untuk berbuat kebaikan secara bersama dalam upaya pengembangan ekonomi masyarakat. Penggunaan nama Tapis Berseri dalam Gerakan Pembangunan ini dikaitkan juga dengan motto Kota Bandar Lampung itu sendiri. Jadi program ini untuk tercapainya pembangunan harus ada keterlibatan masyarakat secara langsung mulai dari tahap perencanaan, pelaksanaan dan pengawasan. Karena pembangunan akan tercapai apabila masyarakat ikut berpartisipasi secara aktif.

Maksud dan tujuan dari program Pembangunan Gerakan Masyarakat Membangun (Gemma) Tapis berseri adalah:

1. Meningkatkan partisipasi dan pemberdayaan masyarakat di kelurahan dalam pembangunan daerah.

2. Proses pembelajaran demokrasi dalam pembangunan.

3. Meningkatkan swadaya masyarakat dalam pelaksanaan dan pelestarian pembangunan.

4. Meningkatkan semangat gotong royong dan kebersamaan dalam melaksanakan proses pembangunan.

5. Mempercepat pembangunan sarana dan prasarana di kelurahan.

6. Menumbuhkan wirausaha baru dari kalangan tunakarya.

7. Membangun usaha yang menjadi produktif.

8. Meningkatkan produktivitas usaha yang sudah produktif. 


\section{Khazanah Sosial, Vol. 2 No. 1: 1-14}

Tingkat Partisipasi Masyarakat Terhadap Program Pembangunan Gemma Tapis Berseri Di Kecamatan

Kedaton Kota Bandar Lampung

Asmaria, Lies Kumara Dewi dan M.Fikri Akbar

9. Meningkatkan pendapatan masyarakat melalui penumbuhan dan peningkatan usaha ekonomi produktif.

Sedangkan, tujuan dari program kegiatan Gerakan Masyarakat Membangun (Gemma) Tapis Berseri yaitu pengentasan kemiskinan dan peningkatan kualitas lingkungan hidup di Kota Bandar Lampung. Sasaran Program Pembangunan Gemma Tapis Berseri terdiri dari :

1. Kegiatan pembangunan infrastruktur perkotaan yang ditujukan untuk mensejahterakan seluruh lapisan masyarakat di setiap kelurahan khususnya bagi masyarakat yang termasuk dalam kelompok tidak mampu dan selain itu juga kegiatan ini diarahkan kepada kelompok masyarakat disetiap kelurahan yang sanggup berswadaya.

2. Pinjaman modal usaha ekonomi produktif (Kredit Ekonomi Kerakyatan) adalah masyarakat yang menjalankan usaha produktif sebagai usaha untuk menunjang pengembangan ekonomi kerakyatan golongan ekonomi lemah di Kota Bandar Lampung untuk kewirausahaan pada bidang perindustrian, perdagangan pertanian tanaman pangan dan holtikultura, perkebunan, perikanan, peternakan dan peningkatan pendapatan petani nelayan kecil serta bidang usaha jasa lainnya.

Jadi, maksud dan tujuan dari Program Pembangunan Gerakan Masyarakat (Gemma) membangun Tapis Berseri yaitu meningkatkan partisipasi masyarakat dan sekaligus memberdayakan masyarakat dalam pembangunan untuk mensejahterakan masyarakat (Muhammad Fikri Akbar et al., 2019).

Kegiatan yang dapat dilakukan melalui Program Pembangunan Gemma Tapis Berseri adalah kegiatan yang sangat dibutuhkan dan bermanfaat bagi masyarakat kelurahan

\section{Partisipasi Masyarakat Dalam Program Pembangunan Gemma Tapis}

Pembangunan sebagai upaya penanggulangan kemiskinan yang dilakukan oleh Pemerintah selalu diharapkan pada tantangan yang semakin berat seiring dengan kemajuan teknologi dan informasi dalam mempengaruhi persepsi dan prilaku masyarakat terhadap tatanan kehidupan, baik ekonomi, sosial budaya dan politik. Oleh karena itu, perlu dilakukan perbaikan pada pendekatan pembangunan yang selama ini ditempuh, yaitu ke arah pemberdayaan masyarakat (Herlintati et al., 2019).

Pelaksanaan pembangunan melalui pendekatan pemberdayaan masyarakat bertujuan agar masyarakat dapat berperan aktif dalam setiap proses pembangunan daerah dalam Ikatan Negara Kesatuan Republik Indonesia (Herdiansah, 2016). Pemberdayaan masyarakat yang dimaksud dititikberatkan pada upaya penguatan peran masyarakat sebagai motor penggerak yang memiliki tanggung jawab dalam pembangunan di lingkungannya masing-masing.

Dalam pelaksanaan Program Pembangunan Gemma Tapis berseri di Kota Bandar Lampung berdasarkan Peraturan Walikota Bandar Lampung Nomor 12 Tahun 2006 tentang Program Pembangunan Gemma Tapis Berseri dapat dilihat dari tingkat partisipasi masyarakat mulai dari tahap perencanaan kegiatan, tingkat pelaksanaan kegiatan dan pengawasan ataupun monitoring kegiatan. Hal ini dilakukan bahwa untuk keberhasilan suatu program kegiatan harus terencana dan sesuai dengan tempat masyarakat yang akan melaksanakan program kegiatan tersebut.

Dalam proses perencanaan kegiatan masyarakat tentunya aktif dalam memberikan masukan serta mengambil keputusan dengan musyawarah Bersama serta Penyelenggaran kebijakan yang banyak melibatkan kab/kota di indonesia memungkin untuk terjadinya berbagai masalah (Muhammad Alfan Alfian, 2019). Dalam pelaksanaan kegiatan masyarakat bersama-sama dengan Kelompok Masyarakat (Pokmas) sebagai lembaga yang melaksanakan program kegiatan Pembangunan Gemma Tapis Berseri dengan tujuan meningkatkan swadaya masyarakat dalam pelaksanaan dan pelestarian pembangunan. 


\section{Khazanah Sosial, Vol. 2 No. 1: 1-14}

Tingkat Partisipasi Masyarakat Terhadap Program Pembangunan Gemma Tapis Berseri di Kecamatan Kedaton Kota Bandar Lampung Asmaria, Lies Kumara Dewi dan M.Fikri Akbar

Dengan adanya partisipasi dari masyarakat ini akan mempercepat pembangunan sarana dan prasarana yang ada, agar dapat diketahui secara terbuka dan diketahui oleh semua unsur masyarakat.

Kegiatan tersebut diharapkan dapat diterima oleh masyarakat dan dilaksanakan tanpa ada unsur terpaksa. Kegiatan ini secara keseluruhan sangat berguna bagi kepentingan masyarakat. Terkait dengan pembangunan, maka pelaksanaan program kegiatan tersebut dilaksanakan untuk kesejahteraan seluruh lapisan masyarakat.

Dalam tahap pengawasan masyarakat harus terlibat di dalamnya bersama Kelompok masyarakat (Pokmas) yang dibentuk oleh Kelurahan untuk menjalankan program tersebut dengan tujuan tidak terjadi penyimpangan dalam pelaksanaan kegiatan baik sarana dan prasarana dibidang pembangunan itu sendiri. Jadi, upaya untuk meningkatkan partisipasi masyarakat melalui tahap perencanaan, kemudian pelaksanaan, dan pengawasan dilakukan dengan swadaya bahwa kegiatan yang dilaksanakan harus sesuai dengan usulan-usulan dan ide-ide dari masyarakat itu sendiri (M Fikri Akbar, 2017) dan nantinya akan terlihat tingkat partisipasi masyarakat terhadap Program Pembangunan Gemma Tapis Berseri.

\section{Partisipasi Masyarakat}

Partisipasi masyarakat yaitu keterlibatan masyarakat dalam proses pengambilan keputusan memberikan masukan ide yang bertujuan memecahkan permasalahan serta mencari jalan keluar untuk memajukan pembangunan masyarakat secara bersama-sama (Sunaryo, 2019). Tingkat partisipasi masyarakat di Kecamatan Kedaton dalam Program Pembangunan Gemma Tapis Berseri diperlihatkan dengan berbagai kegiatan yang telah diimplementasikan di masing-masing kelurahan yang berada di Kecamatan Kedaton sama hal nya seperti demokrasi yang mana Mekanisme demokrasi untuk memilih seseorang yang akan mewakili rakyat dan untuk memimpin.

\section{Analisis Kualitatif}

Hasil kuesioner yang disebarkan kepada 120 responden yang ikut dalam Program Pembangunan Gemma Tapis Berseri di Kecamatan Kedaton, Kota Bandar Lampung memberikan gambaran bahwa untuk variabel penelitian partisipasi masyarakat dengan indikator yaitu tahap perencanaan, tahap pelaksanaan dan tahap pengawasan. Berdasarkan jawaban responden terlihat bahwa sebagian besar atau mayoritas responden menyatakan bahwa mereka tidak mengetahui adanya sosialisasi dari Pokmas mengenai Program Pembangunan Gemma Tapis Berseri.Hasil jawaban responden menunjukkan bahwa responden yang ikut serta dalam memilih pengurus Pokmas pada Program Gemma Tapis Berseri yaitu sebanyak 3 orang atau 2,50\% menyatakan sering, 27 orang atau 22,50\% menyatakan kadang-kadang dan 90 orang atau 75,00 menyatakan tidak pernah. Hasil jawaban responden menunjukkan dari 120 responden yang menjawab bahwa responden diundang oleh Pokmas untuk mendiskusikan Program Kegiatan Pembangunan Gemma Tapis Berseri yaitu sebanyak 33 orang atau 27,50\% menyatakan ya, 69 orang atau $57,50 \%$ menyatakan kadang-kadang, dan yang menyatakan tidak pernah sebanyak 18 orang atau $15,00 \%$.

Hasil jawaban responden menunjukkan bahwa mereka ikut aktif dalam mendiskusikan Program Kegiatan Pembangunan Gemma Tapis Berseri yaitu sebanyak 27 orang atau 22,50\% menyatakan ya, 90 orang atau $75,00 \%$ menyatakan kadang-kadang, dan yang menyatakan tidak pernah sebanyak 3 orang atau 2,50\%. Hasil jawaban responden menunjukkan bahwa masyarakat ikut serta dalam pelaksanaan kegiatan pembangunan Gorong-gorong, Paving Block, Rehab Fasilitas Umum (Pos Jaga, Tempat Peribadatan dan Perbaikan Jalan) Terkait dengan Pembangunan Gemma Tapis Berseri yaitu sebanyak 9 orang atau 7,50\% menyatakan ya, 78 orang atau $65,00 \%$ menyatakan kadang-kadang, dan yang menyatakan tidak pernah sebanyak 33 orang atau $27,50 \%$. Hasil jawaban responden menunjukkan bahwa mereka turut andil dalam Pelaksanaan Program Pembangunan Gemma Tapis Berseri misalnya memberikan sumbangan material maupun dalam bentuk uang yaitu sebanyak 3 orang atau 2,50\% 


\section{Khazanah Sosial, Vol. 2 No. 1: 1-14}

Tingkat Partisipasi Masyarakat Terhadap Program Pembangunan Gemma Tapis Berseri Di Kecamatan Kedaton Kota Bandar Lampung Asmaria, Lies Kumara Dewi dan M.Fikri Akbar

menyatakan ya, responden yang menyatakan bahwa kadang-kadang turut andil dalam memberikan sumbangan material maupun dalam bentuk uang dalam kegiatan Program Pembangunan Gemma Tapis Berseri berjumlah 57 orang atau $47,50 \%$, sedangkan yang menyatakan tidak pernah sebanyak 60 orang atau 50,00\%. Berdasarkan hasil jawaban tersebut, terlihat bahwa mayoritas responden tidak pernah turut andil dalam memberikan sumbangan material maupun dalam bentuk uang. Dengan demikian, tingkat partisipasi masyarakat masih tergolong rendah. Hal tersebut dikarenakan adanya asumsi dari masyarakat bahwa dana atau biaya pembangunan merupakan tanggung jawab dan kewajiban dari pemerintah, dan masyarakat hanya berkewajiban menikmati hasilnya saja.

Hasil jawaban responden menunjukkan bahwa responden ikut serta dalam pelaksanaan pengumpulan dana berupa meminta bantuan sumbangan kepada masyarakat umum untuk menyukseskan kegiatan Program Pembangunan Gemma Tapis Berseri sebanyak 12 orang atau 10,00\% menyatakan ya, 87 orang atau $72,50 \%$ menyatakan kadang-kadang, dan sebanyak 21 orang atau 17,50\% menyatakan tidak pernah. Hasil jawaban responden menunjukkan bahwa responden ikut serta dalam mengawasi pemasukan dana Program Pembangunan Gemma Tapis Berseri melalui hasil laporan kegiatan yaitu tidak ada responden yang menyatakan ya, sebanyak 63 orang atau 52,50\% menyatakan kadangkadang dan sebanyak 57 orang atau 47,50 menyatakan tidak pernah. Hasil jawaban responden menunjukkan bahwa responden ikut serta dalam mengawasi pengeluaran dana Program Pembangunan Gemma Tapis Berseri melalui hasil laporan kegiatan yaitu tidak ada responden yang menyatakan ya, sebanyak 66 orang atau 55,00\% menyatakan kadang-kadang, dan sebanyak 54 orang atau $45,00 \%$ menyatakan tidak pernah. Hasil jawaban responden menunjukkan bahwa responden ikut serta mengawasi kualitas infrastruktur bangunan yang telah dibangun sesuai bestek (rancangan) sehingga dimanfaatkan dengan baik oleh masyarakat umum yaitu tidak ada responden yang menyatakan ya, kemudian responden yang menyatakan tidak sebanyak 63 orang atau 52,50\%, dan yang menyatakan tidak tahu sebanyak 57 orang atau $47,50 \%$. Hasil jawaban responden mengenai partisipasi masyarakat menunjukkan bahwa sebanyak 63 orang atau 52,50\% menyatakan dalam kategori kurang, responden yang menyatakan bahwa partisipasi masyarakat dalam kategori sedang berjumlah 45 orang atau $37,50 \%$, dan yang menyatakan baik sebanyak 12 orang atau $10,00 \%$.

Berdasarkan uraian di atas dapat disimpulkan bahwa partisipasi masyarakat di Kecamatan Kedaton Kota Bandar Lampung termasuk dalam kategori kurang. Dengan demikian, dapat dikatakan bahwa program pembangunan yang dilakukan oleh Pemerintah Kota Bandar Lampung tidak mampu menyerap aspirasi atau partisipasi masyarakat dan hal ini harus diupayakan oleh Kelompok Kerja Masyarakat (Pokmas) untuk diminimalisir dengan lebih mensosialisasikan tujuan program pembangunan tersebut. Hasil kuesioner yang disebarkan kepada 120 responden yang ikut dalam Program Pembangunan Gemma Tapis Berseri di Kecamatan Kedaton, Kota Bandar Lampung memberikan gambaran mengenai variabel penelitian yaitu Program Pembangunan Gemma Tapis Berseri, dijabarkan dalam tabel-tabel berikut ini. Hasil jawaban responden menunjukkan responden yang menjawab bahwa perencanaan Program Pembangunan Gemma Tapis Berseri disesuaikan dengan kondisi perekonomian masyarakat yaitu sebanyak 74 orang atau $61,67 \%$, kemudian 46 orang atau 38,33\% menyatakan kurang, dan tidak ada responden yang menyatakan tidak.

Berdasarkan jawaban responden tersebut di atas terlihat bahwa sebagian besar atau mayoritas responden menyatakan bahwa Program Pembangunan Gemma Tapis Berseri dilaksanakan sesuai dengan kondisi perekonomian masyarakat setempat. Hasil jawaban responden menunjukkan bahwa perencanaan Program Pembangunan Gemma Tapis Berseri disesuaikan dengan kondisi sosial masyarakat yaitu sebanyak 88 orang atau 73,33\% menyatakan ya, 26 orang atau 21,67\% menyatakan 


\section{Khazanah Sosial, Vol. 2 No. 1: 1-14}

Tingkat Partisipasi Masyarakat Terhadap Program Pembangunan Gemma Tapis Berseri di Kecamatan Kedaton Kota Bandar Lampung Asmaria, Lies Kumara Dewi dan M.Fikri Akbar

kurang dan 6 orang atau 5,00 menyatakan tidak. Hasil jawaban responden menunjukkan bahwa perencanaan Program Pembangunan Gemma Tapis Berseri disesuaikan dengan kondisi budaya masyarakat yaitu sebanyak 30 orang atau $25,00 \%$ menyatakan ya, 84 orang atau $70,00 \%$ menyatakan kurang, dan yang menyatakan tidak sebanyak 6 orang atau 5,00\%. Hasil jawaban responden menunjukkan bahwa dalam merencanakan Program Pembangunan Gemma Tapis Berseri Selalu dilandaskan pada esensi masalah yang berada dalam masyarakat yaitu sebanyak 38 orang atau $31,67 \%$ menyatakan ya, 74 orang atau $61,67 \%$ menyatakan kurang, dan yang menyatakan tidak sebanyak 8 orang atau 6,66\%. Hasil jawaban responden menunjukkan bahwa dalam merencanakan Program Pembangunan Gemma Tapis Berseri memprioritaskan kebutuhan masyarakat yaitu sebanyak 30 orang atau $25,00 \%$ menyatakan ya, 75 orang atau 62,50\% menyatakan kurang, dan yang menyatakan tidak sebanyak 15 orang atau $12,50 \%$. Hasil jawaban responden menunjukkan bahwa Pembangunan Gemma Tapis Berseri bidang sarana peribadatan berjalan dengan efektif yaitu sebanyak 53 orang atau $44,17 \%$ menyatakan ya, sebanyak 60 orang atau 50,00\% menyatakan kurang, sedangkan yang menyatakan tidak sebanyak 7 orang atau $5,83 \%$.

Hasil jawaban responden menunjukkan bahwa pembangunan sarana transportasi jalan terutama pemasangan pavling blok sudah terealisasi dengan baik yaitu sebanyak 39 orang atau 32,50\% menyatakan ya, sebanyak 78 orang atau $65,00 \%$ menyatakan kurang, dan sebanyak 3 orang atau 2,50\% menyatakan tidak. Hasil jawaban responden menunjukkan bahwa pembangunan gorong-gorong dan saluran air sudah terlaksana efektif yaitu sebanyak 39 orang atau 32,50\% yang menyatakan ya, sebanyak 81 orang atau $67,50 \%$ menyatakan kurang dan tidak ada responden yang menyatakan tidak. Hasil jawaban responden menunjukkan bahwa program Pembangunan Gemma Tapis Berseri telah terealisasi dengan baik dalam rehabilitasi fasilitas umum yaitu sebanyak 15 orang atau $12,50 \%$ yang menyatakan ya, sebanyak 99 orang atau 82,50\% menyatakan kurang, dan sebanyak 6 orang atau 5,00\% menyatakan tidak. Hasil jawaban responden menunjukkan bahwa program Pembangunan Gemma Tapis Berseri telah terealisasi dengan baik dalam pembangunan pos keamanan yaitu sebanyak 69 orang atau $57,50 \%$ yang menyatakan ya, kemudian responden yang menyatakan kurang sebanyak 51 orang atau 42,50\%, dan tidak ada responden yang menyatakan tidak. Hasil jawaban responden menunjukkan jawaban responden mengenai Program Pembangunan Gemma Tapis Berseri di Kecamatan Kedaton Kota Bandar Lampung yaitu sebanyak 22 orang atau 18,33\% menyatakan dalam kategori kurang, sebanyak 58 orang atau $48,34 \%$ menyatakan sedang, dan yang menyatakan baik sebanyak 40 orang atau 33,33\%.

Berdasarkan uraian di atas, maka dapat ditarik kesimpulan bahwa realisasi Program Pembangunan Gemma Tapis Berseri di Kecamatan Kedaton Kota Bandar Lampung dalam kriteria sedang dan hanya sedikit yang menyatakan dalam kriteria kurang. Dengan demikian, dapat dikatakan bahwa Program Pembangunan Gemma Tapis Berseri sudah sesuai dengan apa yang menjadi kehendak dari masyarakat di Kecamatan Kedaton Kota Bandar Lampung.

\section{Analisis Kuantitatif}

Berdasarkan data yang telah diperoleh dalam penelitian ini, untuk mengetahui hubungan dan pengaruh maka akan dianalisa dengan menggunakan model analisis Korelasi Product Moment, kemudian dilanjutkan dengan alat uji t. Sebelum dimasukkan ke dalam rumus, maka hasil kuesioner yang telah terkumpul dari 120 responden akan ditabulasikan dengan ketentuan sebagai berikut :

1. Sebagai alternatif jawaban yang diberikan mempunyai nilai yaitu :

a. Alternatif jawaban A diberi nilai 3.

b. Alternatif jawaban B diberi nilai 2.

c. Alternatif jawaban $\mathrm{C}$ diberi nilai 1. 


\section{Khazanah Sosial, Vol. 2 No. 1: 1-14}

Tingkat Partisipasi Masyarakat Terhadap Program Pembangunan Gemma Tapis Berseri Di Kecamatan Kedaton Kota Bandar Lampung

Asmaria, Lies Kumara Dewi dan M.Fikri Akbar

2. Menjumlahkan jawaban responden yang sudah diberi nilai, yaitu variabel partisipasi masyarakat $(\mathrm{X})$ lihat pada Lampiran 2 dan menjumlahkan nilai jawaban responden tentang variabel Program Pembangunan Gemma Tapis Berseri $(\mathrm{Y})$ lihat pada Lampiran 3.

3. Kemudian hasil tersebut dimasukkan ke dalam tabel kerja (Lampiran 4).

\section{Analisis Data Penelitian}

Dalam analisis data terdapat langkah-langkah dalam perhitungan yaitu :

\section{Langkah Pertama}

Untuk mengetahui pengaruh partisipasi masyarakat terhadap Program Pembangunan Gemma Tapis Berseri di Kecamatan Kedaton Kota Bandar Lampung, maka penulis membuat tabel kerja terlebih dahulu dalam bentuk nilai dari masing-masing responden seperti pada lampiran 4 ini.

Di mana dalam lampiran 4 tersebut dapat diketahui :

$\begin{array}{lll}\mathrm{N} & = & 120 \\ \sum \mathrm{x} & = & 2010 \\ \sum \mathrm{y} & = & 2824 \\ \sum \mathrm{x}^{2} & = & 34188 \\ \sum \mathrm{y}^{2} & = & 67104 \\ \sum \mathrm{xy} & = & 47598\end{array}$

Selanjutnya dilakukan perhitungan untuk mengetahui besarnya nilai koefisien korelasi Product Moment, sebagai berikut :

$$
\begin{aligned}
r_{x y} & =\frac{n \sum x \cdot y-\left(\sum x\right)\left(\sum y\right)}{\sqrt{\left\{n \sum x^{2}-\left(\sum x\right)^{2}\right\}\left\{n \sum y^{2}-\left(\sum y\right)^{2}\right\}}} \\
& =\frac{(120 x 47598)-(2010)(2824)}{\sqrt{\left\{(120 \times 34188)-(2010)^{2}\right\}\left\{(120 \times 67104)-(2824)^{2}\right\}}} \\
& =\frac{5711760-5676240}{\sqrt{\{62460\}\{77504\}}} \\
& =\frac{35520}{\sqrt{4840899840}} \\
& =\frac{35520}{69576,58} \\
& =0,5105
\end{aligned}
$$

\section{Langkah Kedua}

Untuk mengetahui keeratan hubungan antara partisipasi masyarakat (Variabel X) dan Program Pembangunan Gemma Tapis Berseri (Variabel Y) maka hasil $r_{\mathrm{xy}}$ dikonsultasikan pada interprestasi koefisien korelasi. 


\section{Khazanah Sosial, Vol. 2 No. 1: 1-14}

Tingkat Partisipasi Masyarakat Terhadap Program Pembangunan Gemma Tapis Berseri di Kecamatan

Kedaton Kota Bandar Lampung

Asmaria, Lies Kumara Dewi dan M.Fikri Akbar

Berdasarkan dari konsultasi yang dilakukan pada interprestasi koefisien korelasi tersebut ternyata $r=0,5105$ terletak pada interval antara 0,401-0,600, maka tergolong kriteria sedang. Dengan demikian partisipasi masyarakat mempunyai hubungan dengan tingkat keeratan sedang dalam Program Pembangunan Gemma Tapis Berseri.

\section{Langkah Ketiga}

Untuk mengetahui besarnya pengaruh peranan tokoh masyarakat sebagai pemimpin informal dalam rangka penyelenggaraan pemerintahan desa, maka digunakan rumus Koefisien Penentu (KP).

$$
\begin{aligned}
& \mathrm{KP}=\quad \mathrm{r}^{2} \times 100 \% \\
& =(0,5105)^{2} \times 100 \% \\
& =0,2606 \times 100 \% \\
& =26,06 \%
\end{aligned}
$$

Berdasarkan hasil perhitungan di atas diperoleh hasil $\mathrm{KP}=26,06 \%$, hal ini menunjukkan bahwa partisipasi masyarakat mempunyai pengaruh terhadap Program Pembangunan Gemma Tapis Berseri di Kecamatan Kedaton Kota Bandar Lampung atau dengan kata lain, bahwa Program Pembangunan Gemma Tapis Berseri dipengaruhi oleh partisipasi masyarakat sebesar 26,06\%, sedangkan sisanya $73,94 \%$ dipengaruhi oleh faktor lain yang tidak diteliti.

Langkah selanjutnya yaitu melakukan uji signifikan dengan uji t dengan rumus sebagai berikut :

$$
\begin{aligned}
t & =r \sqrt{\frac{N-2}{1-r^{2}}} \\
& =0,5105 \sqrt{\frac{120-2}{1-(0,5105)^{2}}} \\
& =0,5105 \sqrt{\frac{118}{1-(0,2606)}} \\
& =0,5105(\sqrt{159,59}) \\
& =0,5105 \times 12,63 \\
& =6,448
\end{aligned}
$$

Berdasarkan perhitungan diatas diperoleh $t_{\text {hitung }}$ sebesar 6,448 sedangkan $t_{\text {tabel }}$ pada taraf signifikan atau $5 \%$ atau $\alpha 0,50$ sebesar 2,000 dan $t_{\text {tabel }}$ pada taraf signifikan $1 \%$ atau $\alpha \quad 0,01$ sebesar 2,660 dengan demikian thitung lebih besar dari tabel.

Setelah mengetahui hasil data tersebut maka didasarkan ketentuan dengan penerimaan dan penolakan hipotesis yang kemungkinan sebelumnya yaitu :

1. Jika $t_{\text {hitung }}>t_{\text {tabel, }}$ maka Ho ditolak Ha diterima.

2. Jika $t_{\text {hitung }}<t_{\text {tabel, }}$ maka Ho diterima dan Ha ditolak.

Berdasarkan hubungan ketentuan tersebut maka hipotesis nihil (Ho) ditolak karena $t_{\text {hitung }}$ lebih besar dari tabel. Hal ini berarti partisipasi masyarakat berpengaruh positif dan signifikan terhadap 


\section{Khazanah Sosial, Vol. 2 No. 1: 1-14}

Tingkat Partisipasi Masyarakat Terhadap Program Pembangunan Gemma Tapis Berseri Di Kecamatan

Kedaton Kota Bandar Lampung

Asmaria, Lies Kumara Dewi dan M.Fikri Akbar

Program Pembangunan Gemma Tapis Berseri. Dengan demikian, hipotesis yang penulis ajukan terbukti dan diterima

\section{SIMPULAN}

Partisipasi masyarakat dalam Program Pembangunan Gemma Tapis Berseri di Kecamatan Kedaton Kota Bandar Lampung termasuk dalam kategori kurang, hal tersebut dapat dilihat dari sebanyak 63 orang atau 52,50\% menyatakan dalam kategori kurang, responden yang menyatakan bahwa partisipasi masyarakat dalam kategori sedang berjumlah 45 orang atau 37,50\%, dan yang menyatakan baik sebanyak 12 orang atau 10,00\%. Terdapat hubungan yang erat dengan kriteria sedang antara pastisipasi masyarakat terhadap Program Pembangunan Gemma Tapis Berseri yang ditunjukkan dengan adanya Korelasi Produk Moment sebesar 0,5105, apabila angka tersebut dikonsultasikan dengan daftar interprestasi Koefisien Korelasi ternyata terletak pada interval antara 0,401 - 0,600 yang menunjukkan korelasi sedang. Besarnya pengaruh partisipasi masyarakat terhadap Program Pembangunan Gemma Tapis Berseri adalah sebesar 26,06\%, sedangkan dari perhitungan pengujian hipotesis uji t mendapatkan angka sebesar 6,448 dan hasil $t_{\text {tabel }}$ pada taraf signifikan $5 \%$ sebesar 2,000 dan pada taraf signifikan $1 \% \mathrm{t}$ tabel sebesar 2,660 sehingga $t_{\text {hitung }}$ lebih besar dari $t_{\text {tabel }}$ atau 2,000 $<6,448>2,660$.

\section{DAFTAR PUSTAKA}

Akbar, M Fikri. (2017). STRATEGI PERUBAHAN DALAM USAHA PERENCANAAN PEMBANGUNAN. PROSIDING KOMUNIKASI, 1(1).

Akbar, Muhammad Fikri, Putubasai, E., \& Asmaria, A. (2019). PERAN KOMUNIKASI DALAM PEMBANGUNAN MASYARAKAT. KOMUNIKA, 2(2), 111-127.

Bihamding, H. (2019). Perencanaan Pembangunan Partisipatif Desa. Deepublish.

Deviyanti, D. (2013). Studi tentang Partisipasi Masyarakat dalam Pembangunan di Kelurahan Karang Jati Kecamatan Balikpapan Tengah. Jurnal Administrasi Negara, 1(2), 380-394.

Herdiansah, A. G. (2016). Peran organisasi masyarakat (Ormas) dan lembaga swadaya masyarakat (LSM) dalam menopang pembangunan di Indonesia. Sosioglobal: Jurnal Pemikiran Dan Penelitian Sosiologi, 1(1), 49-67.

Herlintati, H., Jaya, F. H., \& Akbar, F. (2019). PERAN KOMUNIKASI DALAM PEMBANGUNAN SUMBER DAYA MANUSIA. PROSIDING SEFILA, 139-144.

Herlintati, H., Kusumastuti, H., \& Akbar, M. F. (2020). Kemampuan Aparat Pemerintahan Kelurahan dalam Menyelenggarakan Administrasi Pemerintahan di Way Halim Permai Kecamatan Way Halim Kota Bandar Lampung. Politicon: Jurnal Ilmu Politik, 2(1), 13-34.

Lubis, B. S. J., \& Mayarni, M. (2017). Partisipasi Masyarakat dalam Pembangunan Fisik di Kepenghuluan Bangko Pusaka Kecamatan Bangko Pusako Kabupaten Rokan Hilir. Riau University.

Martono, N. (2019). Metode penelitian kuantitatif.

Muhammad Alfan Alfian. (2019). Politik Zonasi dalam Praktik Pendidikan di Indonesia. Politicon: Jurnal Ilmu Politik, 2(1), 117-133.

Ndraha, T. (1990). Membangun Good Governance Di Desa. Ire Perss.

Putri, H. M. (2019). PERAN TOKOH AGAMA DALAM PARTISIPASI POLITIK DI INDONESIA.

Sugiyono, M. (2015). penelitian \& pengembangan (Research and Development/R\&D). Bandung: Penerbit Alfabeta.

Suliyanto, S. E., \& MM, S. (2017). Metode Penelitian Kuantitatif.

Sunaryo, U. P. (2019). PERAN PEMERINTAH DESA DALAM MENDORONG PARTISIPASI POLITIK MASYARAKAT DALAM PEMBANGUNAN. JURNAL POLITICO, 8(3). 


\section{Khazanah Sosial, Vol. 2 No. 1: 1-14}

Tingkat Partisipasi Masyarakat Terhadap Program Pembangunan Gemma Tapis Berseri di Kecamatan Kedaton Kota Bandar Lampung

Asmaria, Lies Kumara Dewi dan M.Fikri Akbar

Susanti, S. (2017). OPTIMALISASI STRATEGI GREEN PRODUCT TERHADAP PERKEMBANGAN UMKM DI BANDAR LAMPUNG DITINJAU DARI ETIKA BISNIS ISLAM (Studi pada Dinas Koperasi dan UKM Kota Bandar Lampung). UIN Raden Intan Lampung.

Tuasikal, A. (2013). Fenomenologis Perencanaan Dan Penganggaran Pemerintah Daerah. Jurnal Akuntansi Universitas Jember, 11(2). 